\title{
Rethinking Language Education in Indonesia
}

\author{
Maslihatul Umami \\ English Department of Educational Faculty \\ State Islamic Studies Institute (STAIN) Salatiga \\ Jl. Tentara Pelajar No. 02 Salatiga, Central Java, Indonesia \\ umamie@gmail.com
}

\begin{abstract}
Language education in Indonesia may be discussed by over viewing the nature of the three language categories in the country: Indonesian language, indigenous languages, and foreign languages. From the picture of how the three groups of languages work and function, the problem raised in this paper is based on two fundamental assumptions. Language education in this multilingual and multicultural country is not done on the context of literacy, on the one hand, and it is not yet considered important in comparison with that of the subjects related to basic science and technology, on the other. After reviewing a number of models of bilingual education and comparing them with what has been done in Indonesia, a preferred model will be offered. Finally, it will also be suggested that language education in Indonesia should be associated with literacy development in a wider sense. Furthermore, meanwhile language education should be given an adequate room; language teaching should be based on the functional use of the existing languages in the country and should be done in tandem with the teaching of content since content is delivered through the medium of language.
\end{abstract}

Keywords: education, language, function, literacy development, content

\begin{abstract}
Abstrak
Pendidikan bahasa di Indonesia dapat dibahas dengan menilik karakteristik tiga kategori bahasa di negara ini : bahasa Indonesia , bahasa pribumi , dan bahasa asing. Dilihat dari gambaran bagaimana tiga kelompok bahasa berfungsi , masalah yang diangkat dalam studi ini didasarkan pada dua asumsi dasar. Pendidikan bahasa di negara multibahasa dan multikultural ini tidak dilakukan pada konteks literasi dan belum dianggap penting dibandingkan dengan mata pelajaran yang berkaitan dengan ilmu dasar dan teknologi. Setelah meninjau sejumlah model pendidikan bilingual dan membandingkannya dengan apa yang telah diterapkan di Indonesia, model
\end{abstract}

REGISTER, VOL. 1, N0. 1, 2008 
pilihan akan diajukan. Akhirnya, turut pula disarankan bahwa pendidikan bahasa di Indonesia harus dikaitkan dengan pengembangan literasi dalam arti yang lebih luas . Selain itu, pendidikan bahasa harus diberikan ruang yang memadai ; pengajaran bahasa harus didasarkan pada penggunaan fungsional dari bahasa yang ada negeri ini dan harus dilakukan bersama-sama dengan pengajaran konten karena konten disampaikan melalui media bahasa .

Kata Kunci : Pendidikan, Bahasa, Fungsi, Pengembangan Literasi, Konten

\section{Introduction}

In order to seek a preferable model of language education in Indonesia, it is necessary to overview the nature of the three language categories in the country: Indonesian language, indigenous languages, and foreign languages. At the same time, in order to find out a suitable model of language teaching, it is also necessary to have a look at how these languages are now taught.

As the national language of the country and the language of a wider communication as well, Indonesian language is used as the medium of instruction at all levels of education from kindergarten to university. It is also taught as a subject for six years in elementary schools, 3 years in secondary schools, 3 years in senior high schools, and one year at university levels (but in the department of Indonesian language and literature, it is taught throughout the course programmed). In the second category, indigenous languages amounting to around 500 are used as communication means within the communities, but are not used as the media of instruction, except the major ones in the areas where students are not yet ready to have Indonesian language as the medium of instruction until year 3 in elementary schools. However, the indigenous languages having significant roles and traditions in arts and literature are taught as subjects from elementary schools to

REGISTER, VOL. 1, N0. 1, 2008 
secondary schools. Similarly, in the departments of indigenous languages, they are taught at university levels throughout the course programmed. Finally, foreign languages especially English, are taught as subjects in secondary schools (3 years), senior high schools (3 years), and at university levels (one year). However, in the department of foreign languages, for example the Department of English, the subjects are also taught throughout the course programmed. Although English is not used as a means of communication in the community, it is a compulsory subject at all levels above, except elementary schools.

The choice of Indonesian language to be the national language meaning that it must be used in any formal administrations and any government sectors, including educational institutions -is historical in nature. It has taken its root since the Indonesian youth declared their oath in 1928 when they believed that they would be successful in struggling against the Dutch colonization if they were unified in terms of "one nation", "one country", and "one language"-Indonesian (Alisyahbana, 1984a: 48). For nation building, the choice is favorable, but from the point of cultural heritage, it has to put aside such big indigenous languages as Javanese or Sundanese having 20 million speakers respectively, much greater than the number of speakers of Malay to be adopted as the national Indonesian language at the time. Another interesting phenomenon of the language education in Indonesia should be put forward first. It is mostly the responsibility of the Department of National Education to conduct language education in the country, but it is the concern of the Language Planning Agency, the Pusat Bahasa, based in Jakarta to maintain the development of Indonesian language and the indigenous languages (excluding foreign languages). Beyond the expectation, the two institutions do not normally make language policies, which are complimentary with each other. For

REGISTER, VOL. 1, N0. 1, 2008 
example, the former has not yet placed language as an important subject compared with those of science and technology, meanwhile the latter considers that language is crucial, so that Indonesian language has been engineered to a certain direction under the government's interference through the so-called "language planning" or " language standardization". With the interference, it can be seen that the development of Indonesia language has been somewhat unnatural in that its phonological, morphological, syntactic, semantic dynamics are strongly controlled. The agency tends to reject whatever influence from both indigenous and foreign languages through very often unavoidable. However, actually Indonesian language has been developing by itself very rapidly, regardless of what the Pusat Bahasa does, and in fact, there have thus been two contradictory influences, one bottom up, and the other top down.

\section{Discussion}

\section{Language educations and literacy}

In such a condition, the education of the three languages may - for some extent, compete with each other in terms of national identity in general and the government policy in particular. Indonesian language education is kept still and firm for the sake of national identity, whereas at the same time indigenous languages are mainly taught as subjects for the purpose of maintaining local cultures (although sometimes only superficially), and foreign languages are often placed as instrumental means.

No doubt that what is done by the Pusat Bahasa is beneficial, but putting the emphasis strongly on the development of Indonesian language and paying less attention to that of indigenous and foreign languages have resulted in some obvious impacts to language teaching. On the other hand, meanwhile the Department of National Education is responsible for the 
implementation of language education in the country, and in fact the department policy has not yet counted language as an important subject in the school curriculum, the policy does not seem to eliminate the impacts. The most profound impact is that the national curriculum should always be contended with what is considered "standard Indonesian language"-even though by definition, the standardization rules are sometimes inconsistentand consequently, the richness of Indonesian dialects is put aside. In so doing, an ambitious target is expected that all of the Indonesian speakers would be able to use the language properly in most of linguistic domains. Another impact is that indigenous languages are practically ignored. It is true that the languages are only used locally and only some of them have a great number of speakers, but in a multilingualcommunity, it is unfair not to promote the languages in the same way as promoting Indonesian language. After all, it is commonly agreed recently that they should be preserved because they can contribute to maintaining local cultures, but real actions in terms of placing them in a well-planed framework of language education as a whole are poorly done. Similarly, foreign languages receive a somewhat bad impact in that they are simply put in the curriculum, except in the relevant university departments, as a means to achieve instrumental purposes, for example to satisfy job markets. The literary subtleties and mutual understanding of foreign cultures through foreign language learning are rarely touched.

In terms of language democracy, then the way to place the three groups of languages creates a linguistic discrimination. Borrowing Phillipsons term (1992), since the way of placement leads to a condition where Indonesian language is to be made superior and is likely to be abandon the other two, "linguistic imperialism" does occur here. Moreover, as the language policy is primarily set up for the sake of nation building, it also

REGISTER, VOL. 1, N0. 1, 2008 
crates a condition, which is often abused by a certain "government elite" to indoctrinate its ideology through employing euphemistic (Indonesian) language. It is, therefore, essential to argue that in language education and language teaching, the three group of languages must be taught relatively equally, and that in the context of language use in different domains, including the government domain, it is not only " linguistic democratization" that still requires more understanding" (Santosa, 1998a) in many aspects of life but also a type of language awareness through which people are fully concerned with how the three groups of languages should actually work and fulfill their functions. Language awareness in education, in particular, is crucial when language is seen as "a goal (language arts, literacy, other languages) and as a vehicle (learning through lecturing, through conversation, through reading, through critical thinking, and so on)"(Van Lier, 1995:98).

The competition of the three groups of languages should not occur if they are placed in accordance with their own functions and roles, and are let open from outside influences with only little intervention for some technical reasons. Likewise, as will be presented below, the three groups of languages will support each other, when they are taught hand in hand under the concept of literacy.

However, as already stated, in comparison with the education of basic science and technology, the three languages are considered peripheral. To make the matter worse, language teaching has not yet been well programmed. It can be seen from the fact that (1) language curriculum is not properly set up to accommodate the nature of the existing languages in the country and the needs required in this changing world, (2) language teaching materials (including books) are not well selected and produced, and (3) most language teachers do not have good qualifications and are not likely to be wellprepared by the government.

REGISTER, VOL. 1, N0. 1, 2008 
As far as the language curriculum is concerned, the national curriculum is merely a type of package to be given to the learners in a uniform way without carefully considering the local diversities backgrounding them. Furthermore, in terms of material sequencing and scope, the allocated time is sometimes not enough to cover the whole materials. Similarly, language books available are usually produced by orders, not as the result of thorough materials selection and sequencing, nor as a reflection of the principles of language acquisition. Finally, language teachers generally deliver the materials in the books by strictly following the teaching guidance (GBPP) in the curriculum without modifying them with regard to the philosophy of language teaching with reference to approach, method, technique, etc. (Cf. Richards \& Rodgers, 1986). For the reasons, language teachers must have significant qualifications in language teaching.

Whereas it should be highlighted that language education must be seen as importantly as the education of the others, there is still a big problem in language teaching in Indonesia seen from the perspective of how language is approached in the learning and teaching implementations. What usually happens is that language is presented as a science offering a set of rules (knowledge), not as a means of oral and written communication (skills). At a school setting, for example, students are usually taught to know about the language as language, not to know of how to use the language in real situations. The research on the literacy of students at the third year elementary schools in Surakarta (Santosa, Wiratno, \& Yustanto,1996) suggests that they are very good at constructing individual sentences, but they are very poor in connecting the sentences to form a type of meaningful discourse. It implies that they are able to write and read sentences as they are, but they cannot build their experiential meaning that shows-following Halliday (1978)-a configuration of "context of situation" and "context of

REGISTER, VOL. 1, N0. 1, 2008 
culture" in some more abstract texts. This is also evident in the language performance of the graduates of senior high schools. They generally cannot communicate their ideas in a systematically accepted language either in oral or written modes. The same evidence applies to their mastery of English as one of foreign languages. The phenomena can also be partly explained from the result of the research above. It shows that the effort of building the academic situations at schools (as part of a literacy effort, if it can be said so) is not always in accordance with what the students face outside the classroom and at their homes. At schools, especially in the classroom, they are forced to have their learning activities with Indonesian language. On the contrary, what they have outside the classroom and at homes is sometimes completely different: many of them rarely use Indonesian language to speak and read, let alone reading materials are not always available. With the case of English, students do not normally use the language outside the classroom either.

Therefore, it can be underlined that teaching languages should not simply deal with passing it to the learners by prescribing language formulas to be learned. A language learner is said to be successful when he or she masters the language formulas and is able to use them in various types of contextual communication both inside and outside the classroom. Ideally, language is taught from the two angels in balance. Teaching a language is not a matter of grammaticalization without encouraging the learners how to use the grammar in real life. This occurs; because-as already stated abovelanguages are not taught under the framework of literacy.

Unfortunately, it is generally assumed in Indonesia, or perhaps in most developing countries, that literacy has to do only with "letters", with how to teach people to be able to read and write. If this is the case, then people are only required to be able to produce and utter words as they are spelt. In other words, they do not involve in reading and writing activities as

REGISTER, VOL. 1, N0. 1, 2008 
ways of self-expression, representation, and cultural interpretation. In a wider sense, in fact, literacy is concerned with any effort allowing people to be well informed and knowledgeable. Jane Mace even suggests that setting up a literacy effort should be more than merely " a solution of the problem of illiteracy"(Mace, 1992: XV). It means that being literate will further include being able to absorb and disseminate information, taking place in different domains with different purposes. People are therefore supposed to be familiar with whatever published in public media either in print or in electronics, and they are likely to be able to give meaning themselves to what they have received and communicate it with others in many ways. So literacy is a multifaceted manifestation of reading, writing, and thinking through which meaning is created within a sociocultural context (Perez, 1998:4). It is always culturally and socially bound.

It is on this context that language education and language teaching in Indonesia must be relied. Nevertheless, in order not to be pessimistic, it can be overviewed that language education in Indonesia has been long leading to a separate path of literacy development where people are only trained to be literate formally either at schools or informally at community groups outside the schools. In both types of educational settings, the learners are fed up with theories of a language or languages with which they merely read and write, without being encouraged to see and experience the multidimensional functions of the language or languages. On the basis of these phenomena, it turns out that Indonesia has so far bred not only "political illiteracy"(Santosa, $1998 b$ ) as a result of the New Order Regime's supremacy for over 30 years, but also cultural, social and mental illiteracies. If the language teaching is done in the way that language is not only seen as knowledge to be understood, but also as skills to be put into practice with respect to its social, 
economic, and cultural political functions, it has been done in line with the principles of literacy.

It is obvious that Indonesia is a multilingual and multicultural country. People use indigenous languages locally and Indonesian language nationally. But some other should use foreign languages, especially English, to cope with international requirements in this global environment. Considering the fact, there must be a layer of multiplicity in association with the modes of expression and representation with the uses of various means, among others, the most salient multimedia, and World Wide Web. In the situation, the application of " multiliteracies" taking into consideration of national diversity and global interrelatedness is required.

Multiliteracies argument suggests the necessity of an open-ended and flexible functional grammar that assists language learners to describe language differences (cultural, sub cultural, regional /national, technical, context-specific, and so on) and the multimodal channels of meaning now so important to communication (Cope \& Kalantzis, 2000:6).

To this extent, rethinking language education in terms of "what to teach" and "how to teach" is essential. In this paper the "what to teach" and the "how to teach" will not be separately discussed in details. Favorably, they will be simultaneously presented in the model of language education in multilingual/multicultural settings and in the model of teaching the language and the content below.

\section{Language education in multilingual and multicultural settings}

There are many multilingual and multicultural countries in the world such as the U.K, the US, and Australia. However, the linguistic map of Indonesia is divergent from those of the countries. Because of the Indonesian multilingual and multicultural uniqueness, language education and language

REGISTER, VOL. 1, N0. 1, 2008 
teaching in this country must also be differently implemented from those in the other multilingual and multicultural countries.

The multilingualism of the three countries, for instance, differs from that in Indonesia for some respects. Firstly, in the three countries the national language is English-which is in fact the language of the world, whereas in Indonesia it is Indonesian language-which is one of the local languages in the globe, and English is the first foreign language.

Secondly, the local languages in the three countries are mostly ethnic languages brought by immigrants from their home countries who do not normally use them in their present community (except in such smaller domains as family), but the local languages in Indonesia are those very vernaculars developing indigenously in the community and are actually used in wider domains, including family, education, workplace, religion, printed/electronic media, and so on. Therefore, it is important to put forward that the multilinguality in the three countries is usually personal, whereas in Indonesia it is societal/communal. That is to say, in the three countries there are a number of bilingual people who are able to speak more than one language -but not necessarily use the ethnic ones in the community, whereas in Indonesia people speak more than one language, and their mother tongues are often the indigenous languages which are indeed used for various reasons in their own community. At the same time, Indonesian language is also used as a wider means of communication.

Thirdly, from the point of view of language acquisition, in bilingual settings, children often acquire Indonesian language soon after or while they acquire their mother tongues. Therefore, in some situations, Indonesian language is the second language of a number of children, but in some others, children have both Indonesian language and indigenous languages as their mother tongues.

REGISTER, VOL. 1, N0. 1, 2008 
Finally, in conjunction with language identity and language attitude, in the three countries people tend to use their ethnic languages when they meet their peers from the same home countries. Maintaining the immigrants, ethnic languages with reference to national identity may not be a real concern in the three countries (Wiratno, 1993). I will put an emphasis on the case of the maintenance and shift of Indonesian language in Sydney, Australia; Cf. Faltis \& Wolfe, Eds. 1999 for the recent of profile of bilingual education in the US, with a particular contrast between immigrants' ethnic languages and the dominant English)

Having ethnic languages map in Indonesia where the necessity of using the three groups of languages is inevitable, a carefully planned language education must be sought. In the following, after a brief review of some models of bilingual education, a potentially suitable bilingual education model will be offered. As bilingual education may mean different things for different ends and there are many models of this sort of education, in this paper, bilingual education does not only refer to a technically simplified notion that it is using two languages for instructional purposes. Rather, it refers to "a wide range of programs that may have different ideological orientations toward linguistic and cultural diversity, different target populations, and different goals for those populations" (Freeman, 1998:2-3, as cited from Hornberger, 1991)

Hornberger's 1991 review on the existing programs of bilingual education provides three models, which are, transitional model, maintenance model, and enrichment model.

The transitional model encompasses all of those bilingual education programs that encourage language minority students to shift to majority language, assimilate to mainstream cultural norms, and be incorporated in to national society. By majority language, Hornberger (1991) means the official language of the national society, and by

REGISTER, VOL. 1, N0. 1, 2008 
minority language she means students whose native language is not the official language of the national society. The maintenance model encompasses all of those programs that encourage language minority student to maintain their native language, strengthen their cultural identity, and affirm their civil rights in the national society. The enrichment model encompasses all of those bilingual education programs that encourage the development of minority language on the individual and collective levels, cultural pluralism at school and in the community, and an integrated national society based on the autonomy of cultural groups (Freeman, 1998: 3).

The most outstanding example of bilingual education quite often discussed in the literature is the one conducted in Canada (See e.g. Swain, 1979 for a brief review; Swain \& Lapkin, 1982, and Baker, 1996 for complete accounts). Called "immersion" programme, which seems to fall into the enrichment model, it was first initiated in 1965 to promote a sociocultural equilibrium in the points of view of two strong groups of Canadian population, French, and English. Depending on the types of immersion (early total, early partial, or late), French and English were used as the media of school instruction in order that students would be equally proficient in both languages. A similar immersion program was later conducted in the US in 1971 to promote student's proficiency of Spanish before they transferred to English academic mainstream (Brinton, Snow \& Wesche, 1989: 8). It belongs to the transitional model, which has then apparently become the most common type of bilingual education in the US, targeting those students defined as "Limited English Proficiency" (Freeman, 1998:4). The maintenance model, which is actually based on language as a right, is less common in the US, but in some parts of the UK there have been some movements insisting on the use of minority languages at schools. For example, "Designated Bilingual Schools" set up in South Wales was aimed to educate students in their home language (Baker, 1996; 356-357). In

REGISTER, VOL. 1, N0. 1, 2008 
Australia, on the other hand, despite the fact that there are some bilingual education programs, which may be mostly categorized into the transitional model, "the future of Australian languages other than English'... is threatened by the failure to provide adequate opportunities for their maintenance and development" because most of Australian schools ignore the minority languages in their curriculum (Smolicz \& Lean, 1979: 67).

Regardless of whatever the name of the program is and whether it is application in different settings, bilingual education has been very popular and applied in many different parts of the worlds, especially in second language learning/teaching programs.

The bilingual education so far known in Indonesia is the one that is not necessarily similar to any of the above categories. In fact, the system of education in the country is Indonesian language monolingual, and therefore Indonesian language is the only formal medium of instruction used in educational institutions. As previously stated, it is true that in certain districts indigenous languages are allowed to be used until Year 3, but it is simply because of a matter of giving chances to the school children to use their indigenous languages before they are ready to transfer to the Indonesian language mainstream. In association with the transitional model, what is done in Indonesia is not the case because it is not aimed at incorporating the subject matter in the curriculum into the indigenous languages teaching objectives. Compared with the maintenance model, it is not the case either since it does not encourage the students to have equal proficiency in indigenous languages and Indonesian language, let alone indigenous languages are not used on purpose as the instructional media. It is also true that in some places indigenous languages are taught from primary schools to senior high schools (and in some other places at university levels as local content), but they are formally put in the curriculum just to show that the

REGISTER, VOL. 1, N0. 1, 2008 
local identities still exist (regardless of how and whether they still do). For the reason, it is clear then that it does not belong to the enrichment model. In addition, from the point of view of bilingual education, foreign languages are not taken into account at all. They are not used as the media of instruction. Except in the relevant departments and in the teaching of language for specific purposes (LSP)- that is teaching by incorporating the content area, they are taught at schools and university levels, as already mentioned, as instrumental purposes.

According to Nababan (1979:209-210), the Indonesian system of education is not designed to promote the multilingual situation in the country, and although it does not mean that the government does not provide the indigenous languages with rooms in the curriculum, it is not designed so because it is based on the general philosophy that the indigenous languages will be learned by children naturally since they are used in the community. It is actually unfortunate that until today the potentiality of Indonesian multilinguality has not yet taken into account in developing language education in the country.

The model being offered here is essentially the enrichment model. The difference is that in this modified model three groups of languages are all together involved, in contrast with the original one normally involving only two. With reference to language rights, literacy principles, multilingual issues, and the central roles of language education, the model will be the one taking into account the teaching of the three groups of languages in a considerably balanced proportion, by not only teaching them as the subjects in the curriculum but also using them as the instruction media in educational institutions. However, with the case of foreign languages, since English is the most dominant among the other foreign languages in Indonesia, English is advisable to be chosen as the instruction medium.

REGISTER, VOL. 1, N0. 1, 2008 
In this model, in addition to using Indonesian language as the medium of instruction at any levels of educational institutions (16 years, plus 2 years in kindergartens), the potential indigenous languages are also proposed to be used as the media of instruction throughout the span of time at elementary schools and secondary schools (9 years, plus 2 years in kindergartens), and English as well is used as the medium of instruction from senior high schools to university levels (around 7 years). In the implementation, the teaching of the three groups of languages as subjects conducted thus far should be continued.

\section{Teaching the language and teaching the content}

To support language teaching, which is implemented in the context of literacy, and to highlight the model of language education under the framework of bilingualism, in the following, the model of language teaching where teaching the language and teaching the content are simultaneously done will be offered.

The issue of teaching the language together with teaching the content has been known for a long time, and it might even take its roots hundreds years ago (Mohan, 1986; Brinton, Snow \& Wesche, 1989; 4). Starting to gain its popularity since 1980s, today it is quite a lot put into practice in various second / foreign language instructional settings (Brinton, 2000; 48).

Basically, it is a model of language teaching that is based on the integration of language and content. "The language curriculum is based directly on the academic needs of the students and generally follows the sequence determined by a particular subject matter in dealing with the language problems which students encounter" (Brinton, Snow \& Wesche, 1989:2). The argument underlying the model is that since the medium of instruction is obviously language, the subject matter instructed would not be understood when the language used is not understood. For example, teaching

REGISTER, VOL. 1, N0. 1, 2008 
biology can be done together with teaching the language used; and therefore, the concepts of biology are only understood if the language is used to figure out the concepts is also understood. In short, content is always delivered through language, and the teaching activity is implemented just by putting four language skills (listening, speaking, reading, and writing) in the subject areas. In other words, it is content-based language teaching where any subjects can be incorporated into it.

Coming back to the modified model proposed above where Indonesian language, the potential indigenous languages, and English (to represent the other foreign languages) are used hand in hand proportionally, the framework of the model of language teaching put forward here can be described as follows.

The potential indigenous languages are expected to be used as the media of delivering those subjects related to moral values, cultures, crafts, traditional arts and music, local literature and philosophy, and the other local contents. English is used as the medium of delivering those subjects related to science and technology. Finally, Indonesian language is used in combination as the general medium of instruction that may cover the subjects ranging from moral values to science and technology.

This type of framework can hopefully eliminate the controversy that the portion of language education nowadays is much smaller than those of the subjects related to science and technology. Since very important roles are given to the three groups of languages in delivering the subjects other than language subjects, the model will automatically employ the teaching of the language as well, and therefore language education will be no longer considered peripheral. On the other hand, from the point of view of the multilingual and multicultural contexts of Indonesia, the model will upgrade the linguistic and cultural heritage of the country. No less important than the

REGISTER, VOL. 1, N0. 1, 2008 
two arguments, the model will in turn make up the development of literacy. With adequate understanding and mastery of the three groups of languages, the opportunities of absorbing and distributing the information from many angles will be opened.

\section{Conclusion}

In elucidating the language education in Indonesia that is multicultural and multilingual, the nature of Indonesian language, indigenous languages, and foreign languages (English) has been discussed. After reviewing a number of bilingual education models and comparing them with what has been done in the country, a preferable model of language education considering the three languages as the media of instruction in addition to being only as the taught subjects is offered. In completion to the model, a language teaching that incorporates content areas into it is also suggested. The application of such kinds of language education and language teaching has been counted as the implementations of literacy development issuing the functional use of the existing languages in this multilingual and multicultural country.

However, putting the proposed model of language education and language teaching into practice is not without consequences. The following implications will presumably appear.First, the promotion of the indigenous languages to be the media of instruction should not be taken as a distortion to the roles of Indonesian language as a means of reaching the "Indonesianness" in terms of modernization (Alisyahbana, 1984b). Rather, in terms of language rights, and by referring to the additional explanation of the 1945 Constitution, such an effort will contribute to coloring the Indonesian cultural plurality. In return, English can play its important role in accelerating the process of Indonesian modernization.

REGISTER, VOL. 1, N0. 1, 2008 
Second, with regard to Van Lier's view on language as a vehicle cited before, a difficult question may come up, whether the indigenous languages expected to be used as the media of instruction can cope with the area of science and technology in response to their vocabulary range, whereas even Indonesian language itself, compared with English, sometimes cannot. But if the two groups of languages are quite open to outside influence, foreign technical terms can be adopted. Similarly, with respect to language planning, the language contacts resulted from the application of the models of language education and language teaching above should be regarded as beneficial aspects for the development of the Indonesian and indigenous languages, not as the dangerous ones destroying the phonological, morphological, syntactic, and semantic properties of the languages.

Third, the application of the models requires some reforms in curriculum design, and in so doing; it will demand a good coordination among the related institutions to be responsible for not only language education but also education in general.

Fourth, in relation to the new curriculum design, the adjoining problems will be things like teacher training, book production, providing facilities and equipment.

\section{References}

Alisyahbana, S.T. 1984a. "The Problem of Minority Languages in the Overall Linguistic Problems of Our Time”. In Coulmas, F. Linguistic Minorities and Literacy. Berlin: Mouton Publishers.

Alisyahbana, S.T. 1984b. "The Concept of language Standardization and Its Application to Indonesian Language”. In Coulmas, F. Linguistic Minorities and Literacy. Berlin: Mouton Publishers.

Baker, C. 1996. Foundations of Bilingual Education and Bilingualism, $2^{\text {nd }}$ edition, Clevedon: Multilingual Matters.

REGISTER, VOL. 1, N0. 1, 2008 
Brinton, D.M. 1999. "Out of the Mouths of Babes: Novice Teacher Insights into Content-Based Instruction". In Faltis, C.J. \& Wolfe, P.M.(Eds.). So Much to Say: Adolescents, Bilingualism, and ESL in the Secondary School. New York: Teachers College Press.

Brinton, D.M., Snow, M.A. \& Wesche, M.B.1989. Content-Based Second language Instruction. New York: Newbury House Publishers.

Clyne,M.1993. Community languages in Australia. Amsterdam: John Benjamins.

Cope, B. \& Kalantzis, M. (Eds.). 2000. Multiliteracies: Literacy Learning and the Design of Social Future. London and New York: Routledge.

Faltis, C.J. \& Wolfe, P.M. (Eds.).1999. So Much to Say: Adolescents, Bilingualism, and ESL in the Secondary School. New York: Teachers College Press.

Freeman, R.D.1998. Bilingual Education and Social Change. Clevedon: Multilingual Matters.

Halliday, M.A.K.1978. Language as Social Semiotic. London: Edward Arnold.

Kesper, L.F. (Ed.). 2000. Content-Based College ESL Instruction. Mahwah, New Jersey: Laurence Erlbaum Associates, Publishers.

Mace, J.1992. Talking about Literacy: Principles and Practice of Adult Literacy Education. London and New York: Routledge.

Mohan, B.A.1986. Language and Content. Reading, M.A.: Addition-Wesley.

Nababan, P.W.J. 1979. "Proficiency Profiles: A Study in Bilingualism and Bilinguality in Indonesia". In Boey, L.K. (Ed.). Bilingual Education. Singapore: Singapore University Press.

Perez, B. 1998. "Literacy, Diversity, and Programmatic Responses". In Perez, B. (Ed.). Sociocultural Contexts of Language and Literacy. Mahwah, New Jersey: Lawrence Erlbaum Associates, Publishers.

REGISTER, VOL. 1, N0. 1, 2008 
Phillipsons, R. 1992. Linguistic Imperialism. Oxford: Oxford University Press.

Richards, J.C \& Rodgers, T.S. 1986. Approaches and Methods in Language Teaching. Cambridge: Cambridge University Press.

Santosa, R. 1998a. "Language Democratization Needs more Understanding”, The Jakarta Post, July 13, 1998.

Santosa, R. 1998b. "RI has bred Political Illiteracy", The Jakarta Post, September 26, 1998.

Santosa, R., Wiratno, T. \& Yustanto, H. 1996. The literacy of the Third Year Elementary Students in Surakarta (Research Report). Surakarta: Faculty of Letters, Sebelas Maret University \& Directorate General of Higher education.

Smolicz, J.J. \& lean, R. 1979. “Australian languages other than English: A Sociological Study of Attitudes”. In Boey, L.K. (Ed.). Bilingual Education. Singapore: Singapore University Press.

Swain, M. 1979. "Bilingual Education for the English-Canadian: Three Models of "Immersion". In Boey, L.K. (Ed.).Bilingual Education. Singapore: Singapore University Press.

Swain, M. \& lapkin, S. 1982. Evaluating Bilingual Education: A Canadian Case Study. Clevedon, Avon: Multilingual Matters.

Van Lier, L. 1995. Introducing Language Awareness. London: Penguin.

Wiratno, T. 1993. "Language Maintenance and Shift of Indonesian among Indonesian Immigrants in Sydney" (Unpublished Course Project Paper), Department of Linguistics. University of Sydney.

REGISTER, VOL. 1, N0. 1, 2008 